\title{
Influence Of Host Community On Industrial Relations Practices And Policies: A Survey Of Agbara Community And Power Holding Company Of Nigeria (PHCN)
}

Christopher O. Chidi, University of Lagos, Nigeria Oluseyi A. Shadare, University of Lagos, Nigeria

\begin{abstract}
This study investigated the influence of host community on industrial relations practices and policies using Agbara community and Power Holding Company of Nigeria PLC as a case. The study adopted both the qualitative and quantitative methods. A total of 120 samples were drawn from the population using the simple random sampling technique in which case every member of the population was given an equal and independent chance of being chosen. However, 75 questionnaires were returned upon which the data analysis was based. This was supplemented with the interwiew method. The response rate is $62.5 \%$. With respect to the reliability of the instrument, the coefficient alpha or Cronbach's alpha is 0.73 , which implies that the instrument is $73 \%$ reliable. The data analysis was carried out with the aid of Statistical Package for Social Sciences (SPSS). The Chi-square statistical technique was used to test the hypotheses at 5\% level of significance. In testing the first hypothesis that PHCN industrial relations policies and practices are independent of its host community, the following variables were subjected to Chisquare test: 1) PHCN industrial relations policies are influenced by public opinion through the use of suggestion schemes $\left(x^{2}=33.07\right.$ with $\left.4 d f ; p<.05\right)$ and 2) customs/traditions of host community influence PHCN industrial relations policies $\left(x^{2}=60.93\right.$ with $\left.4 d f ; p<.05\right)$. In testing the second hypothesis, the result of the chi-square test shows that an inclusive stakeholders' approach is often used in resolving matters of mutual interest involving host community and PHCN $\left(x^{2}=54.23\right.$ with $\left.3 d f ; p<.05\right)$. These results are statistically significant. Therefore, there is evidence to reject the null hypotheses and to conclude that PHCN industrial relations policies and practices are dependent or contingent on its host community. PHCN industrial relations policies and practices are influenced by its host community. The authors therefore recommend the inclusion of the host community as one of the actors in industrial relations. This was relegated to the background by Dunlop (1958) in his categorization of actors in industrial relations.
\end{abstract}

Keywords: host community; industrial relations; practices and policies

\section{INTRODUCTION}

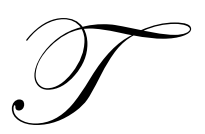

he influence of host community on organizations has attracted the attention of researchers for ages. Industrial relations has been influenced by a variety of circumstances and actors, such as political philosophies, economic imperatives, the role of the State in determining the direction of economic and social developments, the influence of unions and the business community, as well as the legacies of colonial governments (Sriyan, 1997). According to Richardson (1970), industrial relations is as old as industry; and being inherent in industry, it will always remain as a feature of industrial life. Industrial relations is concerned with the systematic study of all aspects of employment relationship (Fajana, 2000). Yesufu (1984) opined that the term industrial relations is accordingly relevant only in the context of the modern market and industrialized economies. It may be defined briefly as "the whole web of human interactions at work which is 
predicated upon and arises out of the employment contract". Industrial relations is an academic discipline and a field of professional practice. According to Dunlop, an industrial relations system, at any one time in its development, is regarded as comprised of certain actors, certain contexts and ideology, which bind the industrial relations system together, and a body of rules created to govern actors in the work place and work community (Dunlop, 1958, as cited in Otobo, 2000). The actors that make up the industrial relations system are as follows: 1) a hierarchy of managers and their representatives in supervision, 2) a hierarchy of workers (non-managerial) and their spokesmen, and 3) specialized governmental agencies and specialized private agencies created by the first two actors concerned with workers, enterprises and their relationship. The context of industrial relations refers to the setting which these actors operate; that is, the larger environment which shapes the conduct of, and the rules established by workers, employers, and the State. Dunlop highlights three aspects of the environment.

First are the technological characteristics of the work place and work community. Technology influences the form of management and employee organization as well as the problems posed for supervision/supervisors. The adopted technology will greatly determine the size and skills of workers and availability of labour. Thus, labour intensive and capital intensive techniques are influenced by technological characteristics of the work place and work community. Technology also influences the health and safety measures in the work place. The adopted technology has far-reaching consequences in determining industrial relations rule-making, such as shift work arrangements. Second are the market/budgetary constraints. The product market or budget is a decisive factor in shaping the rules established by an industrial relations system. More so, the market or budgetary constraints also indirectly affect the technology and other characteristics of the work place, including the size of production and operations. In all, an industrial relations system created and administered by its actors is adaptive to its market and budgetary constraints (Otobo, 2000). More so, the profitability of the enterprise hinges on its product market. Third is the locus and distribution of power in the larger society. The relative distribution of power among the actors in the wider society tends, to a degree, to be reflected within the industrial relations system (Dunlop, 1958). Thus, the distribution of power within the industrial relations system is affected by the distribution of power within the wider society or social system. The wider society is seen as providing certain external influences and constraints.

The actors in given contexts establish rules for the work place and work community. Dunlop (1958) referred to this as the "web of rules" that governs the parties. Thus, the creation of rules is seen as the ultimate aim of the industrial relations system. The rules of the industrial relations system may be expressed in a variety of forms - the regulations and policies of the management, the laws of any worker hierarchy, the regulations, decrees, decisions, awards, orders of governmental agencies, collective bargaining agreements, customs and traditions of the work place and work community. An industrial relations system is integrated by ideology. Ideology connotes a set of ideas and beliefs commonly held by the actors that helps to bind or integrate the system together as an entity. According to Dunlop, each of the actors in an industrial relations system may be said to have its own ideology. Dunlop insists rather strongly that all these ideologies must be sufficiently compatible or consistent to permit a common set of ideas which recognized an acceptable role for each actor. Other prominent theorists, such as Flanders (1970) and Hyman (1975), have shed more light on the concept of industrial relations. A brief description of their ideas about industrial relations is presented in what follows. Flanders (1970) views industrial relations as the study of the institutions of job regulation, as well as a rule-making process. According to Hyman (1975), "industrial relations entails the study of the processes of control over work relations, and among these processes, those involving collective worker organizations and action are of particular concern". All three theories recognize the importance of context. Industrial relations does not exist in a vacuum. All three theories recognize that there are three major actors or participants in industrial relations which corroborate the concept of tripartism or social concertation.

However, with the emergence of transnational organizations and the influence of host communities, emphasis is now shifting from tripartism to "tripartism - plus" with respect to the structure of the actors in industrial relations. The need for a new scenario for actors has been further amplified at the world congress of the International Industrial Relations Association (IIRA) in Japan, now International Labour and Employment Relations Association (ILERA). In addition to the conventional tripartite social partners, more actors, such as consumers, producers, citizens, job seekers, the executive, legislator and judiciary inter alia are listed as taking part in the balancing between competing interests in the labour market (Fajana, 2000). 
The objective of the study is to ascertain if host communities have influence on an organization's industrial relations practices and policies with evidence drawn from the Nigerian context.

\section{LITERATURE REVIEW}

This study leans on the systems theory of industrial relations as proposed by Dunlop (1958), as well as the contingency theory. The contingency theory holds the view that human resource management, including industrial relations practices, is influenced by the organization's environment and circumstances (Legge, 1978, as cited in Armstrong, 2009). The views of Dunlop (1958), Flanders (1970) and Hyman (1975) regarding the scope of issues involved in industrial relations have been presented above and as such, they need not be repeated in this section. The term community has numerous meanings. A community can be a collection of people who share something in common, as in the 'artistic community'- without living in a particular place. It can be a feeling of connection to others or of belonging and identification as in 'community spirit'. It can also be a collection of people who do related kinds of work as in 'the health community' or 'the academic community'. Its most common and concrete sense is a collection of people who share a geographical territory and some measure of inter-dependency that provides the reason for living in the same place (Johnson, 2000). In general, however, geographically-based communities involve living, working, and carrying out the basic activities of life within a territory defined by residents as having geographic identity, most notably reflected in the assigning of place names and the drawing of boundaries. Thus, an idea of community includes a fairly strong feeling of belonging and mutual commitment based on a homogeneous culture, shared experience and close interdependency. Sociologists have developed two dimensions for distinguishing among different types of communities - rural/urban community and traditional/modern community. A rural community is characterized by a small, sparsely settled, relatively homogeneous population that engages primarily in agriculture (although there are exceptions to this, especially in small towns and villages within commuting distances of cities in industrial societies).

An urban community has a large, densely settled, and relatively heterogeneous population. According to Johnson (2000), the designation of a community as urban is somewhat arbitrary. The U.S. Census Bureau, for example, draws the line at 2,500 people; although to qualify as an 'urbanized area', a city and surrounding territory must contain at least 50,000 people. The traditional/modern dimension focuses on cultural differences. Traditional communities are more homogeneous and resistant to new ideas. They are less technological and less dependent on mass media. They also place a lower value on literacy and schooling and a higher value on religion (Johnson, 2000). In contrast, modern communities are culturally heterogeneous, more secular than religious, and dependent on sophisticated technology and complex division of labour. They also make use of highly developed mass media and formal education. Omololu (2005) posited that the word community is used to refer to a group of people who live within the same geographically defined locality and who interact, to some extent, directly or indirectly. Members of a community have something in common - usually a shared geographical territory. This binds them and creates a common interest in them to protect their community. The idea of community also suggests that members have common values, beliefs and objectives, although they do not necessarily have to belong to the same ethnic, cultural or religious group. From the foregoing, therefore, it is appropriate to state that Agbara community selected for this study is a modern and urban community since it possesses the features typical of urban and modern community.

A host community, on the other hand, refers to the immediate locale or a place where something happens. In this case, the host community of Power Holding Company of Nigeria (PHCN) is Agbara community since it is the community in which PHCN operates. The business of PHCN is to generate, transmit and distribute a supply of electricity to its immediate community. It used to be known as National Electric Power Authority (NEPA). According to Armstrong (2009), HR policies and activities are valid only if they are related to the situation of the organization. This is the thrust of the contingency theory, which implies that industrial relations and HR policies and practices are contingent upon the organizational context within which they operate.

Matanmi (2007) noted that 'the working environment is particularly important in the assessment of the quality of an employment relationship because the functionality of an employment relationship cannot be divorced from the social and physical environment of the work place'. This working environment could be internal or external. The host community constitutes the external environment. This implies that host communities have implications for industrial relations practices. For example, the crises in the Niger Delta region of Nigeria have 
impacted on industrial relations practices of major oil companies operating in the littoral states. This could take the form of community relations, corporate social responsibility, plant shut-down, relocation of personnel to safer zones and layoffs, to mention a few. The management of organizations must accommodate the needs and interests of the host community in terms of social infrastructure, such as roads, potable drinking water, recreation centres, playing ground, and sporting facilities which they share with their host communities. It is part of the social responsibility of management to be responsive to the welfare needs of their local or host community. They should have and operate policies that satisfy the aspirations of the members of the community in which they are located (Ogundele, 2005). Management of organizations must evolve and ensure a peaceful industrial relationship in their host communities by employing the method of social dialogue and partnership in addressing problems of industry-community relationships.

\section{RESEARCH HYPOTHESES} alpha level.

Two null hypotheses were formulated for the purpose of this study and tested at $5 \%$ level of significance or

Hypothesis 1: PHCN industrial relations policies and practices are independent of its host community.

Hypothesis 2: An inclusive stakeholders' approach is not often used in resolving matters of mutual interests involving host community and PHCN.

\section{METHOD}

The authors adopted both the qualitative and quantitative methods which, according to Haralambos and Holborn (1995), is referred to as methodological pluralism or triangulation. With a view to eliciting information from respondents, a self-developed survey using the 5-point Likert scale ranging from strongly agree (5) to strongly disagree (1) was deployed. The instrument has 21 items and the questionnaire was divided into two sections. Section A consists of 16 items which measured the perceived influence of host community on industrial relations practices and policies. Section B consists of five items which examined the demographic profiles of respondents. The interview method was used to corroborate some of the items in the survey. The survey of perceptions took place at Power Holding Company of Nigeria PLC located at Agbara Industrial Estate. All employees of PHCN, Agbara district, and residents of the host community constitute the population of the study. A total of 120 samples were drawn from the population using the simple random sampling technique in which case every member of the population was given an equal and independent chance of being chosen. However, 75 questionnaires were returned upon which the data analysis was based. This represents a $62.5 \%$ response rate. With respect to reliability of the instrument, the coefficient alpha or Cronbach's alpha is 0.73 , which implies that the instrument is $73 \%$ reliable. The data analysis was carried out with the aid of Statistical Package for Social Sciences (SPSS). The Chi-square statistical technique was used to test the hypotheses at $5 \%$ level of significance. Some of the limitations of the study are the poor attitudes of respondents to the survey. In spite of the authors' earlier letter to the Business Manager of PHCN, Agbara District, of our proposed research for which approval was given, many of the staff were somewhat reluctant to complete the questionnaire. Some were afraid to supply information which delayed the completion of the research. This is one of the limitations of the study. Therefore, there is need for ethical education in research in the Nigerian environment. More so, the dearth or limited current resource materials, such as journal articles on host community and industrial relations in the Nigerian context, is also a limitation of the study 


\section{RESULTS}

Table 1 shows the descriptive statistics of primary data generated from the field.

Table 1: Descriptive Statistics Of Primary Data

\begin{tabular}{|c|c|c|c|c|c|c|c|c|c|}
\hline $\mathbf{S} / \mathbf{N}$ & STATEMENTS & $\mathbf{N}$ & SA & $\mathbf{A}$ & $\mathbf{U N}$ & D & SD & MIS & $\begin{array}{l}\text { VARIATION } \\
\text { RATIO } \\
\end{array}$ \\
\hline & & & 5 & 4 & 3 & 2 & 1 & & \\
\hline 1. & $\begin{array}{l}\text { In the employment of non-managerial } \\
\text { employees, the organization gives priority } \\
\text { to indigenes of host community. }\end{array}$ & 75 & $\begin{array}{c}(20) \\
26.7 \%\end{array}$ & $\begin{array}{c}(22) \\
29.3 \%\end{array}$ & $\begin{array}{l}(15) \\
20 \%\end{array}$ & $\begin{array}{c}(13) \\
17.3 \%\end{array}$ & $\begin{array}{l}(5) \\
6.7 \%\end{array}$ & 3.52 & 1.245 \\
\hline 2. & $\begin{array}{l}\text { In handling complaints from host } \\
\text { community, the adoption of social } \\
\text { dialogue has been fruitful }\end{array}$ & 75 & $\begin{array}{l}(21) \\
28 \%\end{array}$ & - & $\begin{array}{l}(42) \\
56 \%\end{array}$ & $\begin{array}{c}(8) \\
10.7 \%\end{array}$ & $\begin{array}{c}(4) \\
5.3 \%\end{array}$ & 4.07 & .777 \\
\hline 3. & $\begin{array}{l}\text { PHCN supports the education of } \\
\text { underprivileged members of host } \\
\text { community through scholarship and } \\
\text { bursary awards. }\end{array}$ & 75 & $\begin{array}{c}(4) \\
5.3 \%\end{array}$ & $\begin{array}{c}(9) \\
12 \%\end{array}$ & $\begin{array}{l}(12) \\
16 \%\end{array}$ & $\begin{array}{c}(28) \\
37.3 \%\end{array}$ & $\begin{array}{c}(22) \\
29.3 \%\end{array}$ & 2.27 & 1.166 \\
\hline 4. & $\begin{array}{l}\text { In the employment of managerial } \\
\text { personnel, the host community lobbies for } \\
\text { the placement of indigenes of host } \\
\text { community. }\end{array}$ & 75 & $\begin{array}{c}(10) \\
13.3 \%\end{array}$ & $\begin{array}{c}(22) \\
29.3 \%\end{array}$ & $\begin{array}{l}(15) \\
20 \%\end{array}$ & $\begin{array}{c}(17) \\
22.7 \%\end{array}$ & $\begin{array}{c}(11) \\
14.7 \%\end{array}$ & 3.04 & 1.289 \\
\hline 5. & $\begin{array}{l}\text { PHCN industrial relations policies are } \\
\text { influenced by public opinion through the } \\
\text { use of suggestion schemes. }\end{array}$ & 75 & $\begin{array}{c}(13) \\
17.3 \%\end{array}$ & $\begin{array}{c}(32) \\
42.7 \%\end{array}$ & $\begin{array}{l}(18) \\
24 \%\end{array}$ & $\begin{array}{c}(10) \\
13.3 \%\end{array}$ & $\begin{array}{c}(2) \\
2.7 \%\end{array}$ & 3.59 & 1.015 \\
\hline 6. & $\begin{array}{l}\text { Customs/traditions of host community } \\
\text { influence PHCN industrial relations } \\
\text { policies }\end{array}$ & 75 & $\begin{array}{l}(3) \\
4 \%\end{array}$ & $\begin{array}{c}(41) \\
54.7 \%\end{array}$ & $\begin{array}{l}(12) \\
16 \%\end{array}$ & $\begin{array}{c}(13) \\
17.3 \%\end{array}$ & $\begin{array}{l}(6) \\
8 \%\end{array}$ & 3.29 & 1.063 \\
\hline 7. & $\begin{array}{l}\text { Youth restiveness of host community } \\
\text { poses security danger or threat to PHCN }\end{array}$ & 75 & $\begin{array}{l}(33) \\
44 \%\end{array}$ & $\begin{array}{c}(29) \\
38.7 \%\end{array}$ & $\begin{array}{l}(9) \\
12 \%\end{array}$ & $\begin{array}{l}(3) \\
4 \%\end{array}$ & $\begin{array}{c}(1) \\
1.3 \%\end{array}$ & 4.20 & .900 \\
\hline 8. & $\begin{array}{l}\text { An inclusive stakeholders' approach is } \\
\text { often used in resolving matters of mutual } \\
\text { interests involving host community and } \\
\text { PHCN. }\end{array}$ & 75 & $\begin{array}{l}(18) \\
24 \%\end{array}$ & $\begin{array}{l}(45) \\
60 \%\end{array}$ & $\begin{array}{c}(7) \\
9.3 \%\end{array}$ & - & $\begin{array}{c}(5) \\
6.7 \%\end{array}$ & 4.01 & .780 \\
\hline 9. & PHCN policies are community-friendly & 75 & $\begin{array}{c}(16) \\
21.3 \%\end{array}$ & $\begin{array}{c}(31) \\
41.3 \%\end{array}$ & $\begin{array}{l}(14) \\
18.7 \%\end{array}$ & $\begin{array}{l}(12) \\
16 \%\end{array}$ & $\begin{array}{c}(2) \\
2.7 \%\end{array}$ & 3.63 & 1.075 \\
\hline 10. & $\begin{array}{l}\text { PHCN is a good corporate citizen and is } \\
\text { so viewed or perceived by the host } \\
\text { community. }\end{array}$ & 75 & $\begin{array}{c}(8) \\
10.7 \%\end{array}$ & $\begin{array}{c}(22) \\
29.3 \%\end{array}$ & $\begin{array}{l}(21) \\
28 \%\end{array}$ & $\begin{array}{c}(20) \\
26.7 \%\end{array}$ & $\begin{array}{c}(4) \\
5.3 \%\end{array}$ & 3.13 & 1.095 \\
\hline 11. & $\begin{array}{l}\text { Host community prompt service delivery } \\
\text { remains the cardinal management } \\
\text { philosophy of PHCN. }\end{array}$ & 75 & $\begin{array}{l}(18) \\
24 \%\end{array}$ & $\begin{array}{c}(28) \\
37.3 \%\end{array}$ & $\begin{array}{c}(14) \\
18.7 \%\end{array}$ & $\begin{array}{c}(11) \\
14.7 \%\end{array}$ & $\begin{array}{c}(4) \\
5.3 \%\end{array}$ & 3.60 & 1.162 \\
\hline 12. & $\begin{array}{l}\text { PHCN is responsive to the plight of host } \\
\text { community }\end{array}$ & 75 & $\begin{array}{l}(12) \\
16 \%\end{array}$ & $\begin{array}{c}(38) \\
50.7 \%\end{array}$ & $\begin{array}{c}(9) \\
12 \%\end{array}$ & $\begin{array}{l}(12) \\
16 \%\end{array}$ & $\begin{array}{c}(4) \\
5.3 \% \\
\end{array}$ & 3.56 & 1.106 \\
\hline 13. & $\begin{array}{l}\text { PHCN has sound and robust community } \\
\text { relations }\end{array}$ & 75 & $\begin{array}{c}(13) \\
17.3 \%\end{array}$ & $\begin{array}{c}(34) \\
45.3 \%\end{array}$ & $\begin{array}{c}(11) \\
14.7 \%\end{array}$ & $\begin{array}{c}(14) \\
18.7 \%\end{array}$ & $\begin{array}{l}(3) \\
4 \% \\
\end{array}$ & 3.53 & 1.107 \\
\hline 14. & $\begin{array}{l}\text { PHCN has been keen on promoting safe } \\
\text { and hazard-free business environment } \\
\text { within its host community. }\end{array}$ & 75 & $\begin{array}{l}(15) \\
20 \%\end{array}$ & $\begin{array}{c}(46) \\
61.3 \%\end{array}$ & $\begin{array}{c}(4) \\
5.3 \%\end{array}$ & $\begin{array}{c}(10) \\
13.3 \%\end{array}$ & - & 3.88 & .885 \\
\hline 15. & $\begin{array}{l}\text { Community surveillance and policing are } \\
\text { the preoccupations of PHCN in liaison } \\
\text { with host community. }\end{array}$ & 75 & $\begin{array}{l}(9) \\
12 \%\end{array}$ & $\begin{array}{l}(33) \\
44 \%\end{array}$ & $\begin{array}{c}(23) \\
30.7 \%\end{array}$ & $\begin{array}{c}(10) \\
13.3 \%\end{array}$ & - & 3.55 & .874 \\
\hline
\end{tabular}

Source: Field Survey, 2010.

Legend: $\mathrm{N}=$ Respondents: $\mathrm{SA}=$ strongly agree: $\mathrm{A}=$ Agree: $\mathrm{UN}=\mathrm{Undecided}$ / indifference: $\mathrm{D}=\mathrm{Disagree}: \mathrm{SD}=\mathrm{Strongly}$ disagree: MIS= Mean Item Score: Variation ratio $=$ Standard deviation 


\section{DISCUSSIONS OF FINDINGS}

In this section, the demographic profiles of respondents, respondents' opinions or perceptions, and findings from the test of hypotheses are presented. With respect to demographic profile, sex distribution of respondents revealed that out of the 75 respondents, 51 were male, representing $68 \%$, while 24 were female, representing $32 \%$. Age distribution of respondents indicated that those younger than 20 years of age were $3(4 \%)$; 20-29 years were 15 (20\%); 30-39 years were 26 (34.6\%); 40-49 years were 23 (30.7\%); and those 50 years and older were 8 (10.7\%). From the foregoing, therefore, one can conclude that the majority of respondents were between the ages of 30 and 39 years, followed by those between the ages of 40 and 49 years. With respect to marital status of the respondents, out of the 75, $42(56 \%)$ were married, $24(32 \%)$ were single, $6(8 \%)$ were separated, and $3(4 \%)$ were divorced. Regarding respondents' educational qualifications, 5 (6.7\%) possessed a school certificate, $14(18.7 \%)$ were holders of OND, 18 (24\%) had the HND, 23 (30.7\%) had a first degree, $8(10.7 \%)$ had a masters degree, and holders of professional diploma were $2(2.7 \%)$, while respondents with other qualifications were $5(6.7 \%)$. None of the respondents possessed a Ph.D degree. With respect to category of respondents, 46 (61.3\%) were staff of PHCN and $29(38.7 \%)$ were residents of host community.

In testing the first hypothesis that PHCN industrial relations policies and practices are independent of its host community, the following variables were subjected to Chi-square test: 1) PHCN industrial relations policies are influenced by public opinion through the use of suggestion schemes $\left(x^{2}=33.07\right.$ with $\left.4 \mathrm{df} ; p<.05\right)$ and 2$)$ Customs/traditions of host community influence PHCN industrial relations policies ( $x^{2}=60.93$ with $4 \mathrm{df} ; p<.05$ ). These results are statistically significant. There is evidence, therefore, to reject the null hypothesis and to conclude that PHCN industrial relations policies and practices are dependent or contingent on its host community. PHCN industrial relations policies and practices are influenced by its host community, which implies that they are not independent of its host community. This finding is consistent with the views of Dunlop (1958) who argued that industrial relations policies and practices are affected by the contextual or operating milieu: 1) Armstrong (2009) who opined that HR policies and activities are valid only if they are related to the situation of the organization; 2) Matanmi (2007) who argued that 'the working environment is particularly important in the assessment of the quality of an employment relationship because the functionality of an employment relationship cannot be divorced from the social and physical environment of the work place, and 3) Ogundele (2005) who posited that organizations should have and operate policies that satisfy the aspirations of the members of the community in which they are located. In testing the second hypothesis that an inclusive stakeholders' approach is not often used in resolving matters of mutual interests involving host community and PHCN, the result of the chi-square test shows that an inclusive stakeholders' approach is often used in resolving matters of mutual interest involving host community and PHCN ( $x^{2}=54.23$ with $\left.3 \mathrm{df} ; p<.05\right)$. This confirms the functionality of the existing consultative forum set up by $\mathrm{PHCN}$ to interact with representatives of the host community.

Statement 1 with a mean item score of 3.52 reveals that there is a great consensus that in the employment of non-managerial employees or junior employees, PHCN gives priority to indigenes or residents of the host community. This is supported by the fact that an organization must be socially responsible to its host community in terms of employment creation and generation. It was discovered, in the course of the study, that the Agbara district is responsible for the engagement of junior workers, while senior employees are employed at their zonal office located at Marina. However, applications of senior employees could be collected at the district and sent to its zonal office for final employment decisions.

Statement 2 with a mean item score of 4.07 indicates a considerable agreement among respondents that in handling complaints from the host community, the adoption of social dialogue has been fruitful. Social dialogue is one of the hallmarks of achieving a peaceful industrial relations climate where the inputs of all stakeholders are sought in resolving issues of divergent and mutual interest.

Statement 3 with a mean item score of 2.27 reveals a general disagreement that PHCN supports the education of underprivileged members of the host community through scholarship and bursary awards. This implies that the organization, to some extent, pays lip service to scholarship and bursary awards to residents of the host community. This is supposed to be another aspect of corporate social responsibility. 
Statement 4 with a mean item score of 3.04 reveals, to a large extent, that the host community does not lobby for the placement or employment of indigenes in managerial positions. This is a confirmation of the fact that the district, as earlier stated, does not have the jurisdiction to engage managerial personnel. Applications of managerial and senior personnel are forwarded to the zonal office where employment decisions are finalized. More so, within the host community, those with the requisite qualifications and experiences for managerial positions may be lacking.

Statement 5 with a mean item score of 3.59 indicates reasonable consensus among respondents that PHCN industrial relations policies are affected by public opinions. This is corroborated by the fact that there exists a forum called "Consumer Consultative Meeting", whereby the management of PHCN meets with the community representatives to exchange ideas on the way forward for better service delivery and to promote good community relations.

Statement 6 with a mean item score of 3.29 reveals, to some extent, that the customs/traditions of the host community do influence PHCN industrial relations policies. To support this statement, during the course of the survey it was discovered that one of the highly respected traditional chiefs in the area visited PHCN office and was not willing to follow the organization's visitors' procedure by not signing the visitors' form. He beat all security networks and went straight to the office of the Business Manager to report that he was badly attended to at the gate. The security guard was made to apologize to him just to make peace. This action runs counter to the policy of the organization, except for the African culture which demands that elders and traditional/influential personalities should be treated with respect and should be held in high esteem.

Statement 7 with a mean item score of 4.20 reveals a general agreement among respondents that youth restiveness of the host community poses security danger or threat to PHCN. To a great extent, the Agbara community has been peaceful devoid of youth restiveness comparable to what exists in the Niger Delta. No wonder a lot of blue chip companies are doing well in the area. The community is also witnessing a quantum leap in the area of development as a result of the presence of large manufacturing and service companies located in the community.

Statement 8 with a mean item score of 4.01 shows that a considerable agreement exists among respondents that in resolving matters of mutual interests involving PHCN and the host community, an inclusive stakeholders' approach is often used. This also confirms statement 2 with a mean item score of 4.07 .

Statement 9 with a mean item score of 3.63 reveals that the respondents, to some extent, agreed that PHCN policies are community friendly.

Statement 10 with a mean item score of 3.13 depicts that PHCN is, to some extent, a good corporate citizen.

Statement 11 with a mean item score of 3.60 reveals, to a large extent, the commitment of PHCN for prompt service delivery to the host community in spite of its limited finances.

Statement 12 with a mean item score of 3.56 reveals, to a large extent, that PHCN is responsive to the plight of the host community. relations.

Statement 13 with a mean item score of 3.53 suggests that PHCN has sound and robust community

Statements 14 and 15 with mean item scores of 3.88 and 3.55 , respectively, indicate that community surveillance and policing are embarked upon by both PHCN and the host community and that PHCN is a promoter of safe and hazard-free environment within its host community.

With respect to the analyses of qualitative questions, as could be found in item 16 in the questionnaire, many of the respondents observed other areas where the host community has influenced PHCN industrial relations policies and practices. These are in the form of a forum of consumer consultative meeting where the management of 
PHCN and the representatives of the host community interact. Host community is also involved in providing security of PHCN equipment and installations. They suggested the need for regular meetings with the stakeholders of the host community and PHCN management, as well as the need for social dialogue and friendly community relations.

\section{CONCLUSION}

This study set out to investigate the influence of host community on industrial relations practices and policies, with evidence drawn from Power Holding Company of Nigeria PLC in Agbara community. The objective is to ascertain if host communities have influence on an organization's industrial relations practices and policies. Our findings revealed that the industrial relations practices and policies of PHCN PLC, Agbara are not independent of its host community. This is a confirmation of the views and findings of leading theorists and researchers in the field of industrial relations and is consistent with the views of (Dunlop, 1958; Ogundele, 2005; Matanmi, 2007 \& Armstrong, 2009). Thus, context or operating milieu has implications for industrial relations practices and policies. The authors therefore recommend the inclusion of the host community as one of the actors in industrial relations. This was relegated to the background by Dunlop (1958) in his categorization of actors in industrial relations.

\section{AUTHOR INFORMATION}

Chidi, O. Christopher, B.Sc (Hons), M.Sc., and Ph.D. (in view) in Industrial Relations \& Personnel Management. $\mathrm{He}$ is a faculty member of the department of Industrial Relations and Personnel Management, Faculty of Business Administration, University of Lagos, Nigeria. He possesses considerable experience in the theory and practice of HRM and Industrial Relations in the public and private sectors. He teaches courses in HRM, Industrial Relations, Research Methods, Organizational Behaviour, Industrial Psychology, Industrial Sociology and Business Communication. His research interests include Human Capital Resourcing, Employee Retention, HRM, Industrial Relations and Organizational Behaviour. He belongs to the following professional associations, ACIPMN, ANITAD and MNIRA.

Shadare, Oluseyi A. holds a Bachelor of Arts and Master of Industrial Relations degrees from the University of Ibadan, Nigeria. He earned his PhD from the same University in human resource management, and a Bachelor of Laws (LLB) degree from University of Lagos. He was called to the Nigerian Bar in 2006. Seyi is currently a faculty member of the Department of Industrial Relations and Personnel Management, University of Lagos, Nigeria. He has extensive experience in the field of Human Resource Management and Industrial Relations, Insurance Marketing and Business Law. He teaches at the undergraduate, graduate and executive levels at the University of Lagos. His research interests are Industrial Relations, Human Resource Management and Labor relations. He has also published several articles, book chapters and conference papers on diverse topics. He is an associate member of the following professional bodies: ACIPMN, ACIM, and member NBA.

\section{REFERENCES}

1. Armstrong, M. (2009). Armstrong's Handbook of Human Resource Management Practice. (11 $1^{\text {th }}$ ed.). U.K: Kogan Page Ltd.

2. Fajana, S. (2000). Industrial Relations in Nigeria: Theory and Features, $\left(2^{\text {nd }}\right.$ ed). Lagos: Labofin and Company

3. Flanders, A. (1970). Management and Unions: The Theory and Reform of Industrial Relations. London: Faber and Faber.

4. Haralambos, M. \& Holborn, M. (1995). Sociology: Themes \& Perspectives $\left(4^{\text {th }}\right.$ Ed.), U.K.: Collins Educational

5. Hyman, R. (1975). Industrial Relations: A Marxist Introduction. London: Macmillan

6. Johnson, A.G. (2000). The Black well Dictionary of Sociology: A Users Guide to Sociological Language $\left(2^{\text {nd }}\right.$ ed). USA: Blackwell Publishers

7. Matanmi, S. (2007). Employment Relationships that Endure: Lessons for Nigeria An Inaugural Lecture Series. Lagos State University.

8. Ogundele, O.J.K (2005). Management and Organization: Theory and Behaviour. Lagos: Molofin Nominee. 
9. Omololu, S. (2005). Community Policing and National Integration in Nigeria. In Akinyele, R.T. (ed)

Contemporary Issues on Boundaries and Governance in Nigeria. Lagos: Franked Publishers

10. Otobo, D. (2000). Industrial Relations: Theory and Controversies. Lagos: Malthouse Press Ltd.

11. Richardson, J.H. (1970). An Introduction to the Study of Industrial Relations. London: George Allen \& Unwin Ltd

12. Sriyan de Silva (1997). The Changing Focus of Industrial Relations and Human Resource Management ILO Workshop on Employers' Organizations. Internet Source

13. Yesufu, T. M. (1984). The Dynamics of Industrial Relations: The Nigerian Experience. Ibadan: University Press Ltd. 


\section{NOTES}

